\title{
FLAVONOIDS OF Adonis wolgensis
}

N. F. Komissarenko, V. Ya. Yatsyuk,

UDC 547.972 and É. P. Korzennikova

In a study of the epigeal part of Adonis wolgensis Stev., the extracts were found to contain the hydroxycoumarins scopoletin and umbelliferone, and also flavonoid substances, which we re separated on a column of polyamide sorbent. The column was eluted with chloroform containing various proportions of ethanol. The eluates obtained with chloroform containing $5 \%$ of ethanol yielded a flavonoid aglycone $\left(\mathrm{C}_{15} \mathrm{H}_{10} \mathrm{O}_{5}, \mathrm{mp} 348-350^{\circ} \mathrm{C}\right)$, which was identified as apigenin. With an increase in the concentration of etha-

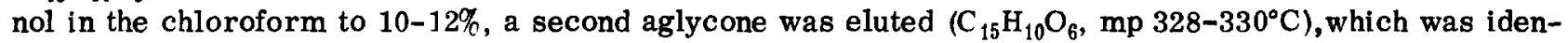
tified as luteolin. A further increase in the concentration of ethanol to $15-18 \%$ led to the elution of a Cglycoside $\left[\mathrm{C}_{21} \mathrm{H}_{10} \mathrm{O}_{11}, \mathrm{mp} 262-267^{\circ} \mathrm{C},[\alpha]_{\mathrm{D}}^{20}+20 \pm 2^{\circ}\right.$ (c 1.0; ethanol)], which was identified as orientin [1].

The substances were identified by their physicochemical properties and IR and UV spectra. The latter we re taken with ionizing and complex-forming reagents. Mixtures of the flavonoids obtained with authentic samples gave no depressions of the melting points.

This is the first time that flavonoid substances have been obtained from A. wolgensis.

\section{LITERATURE CITED}

1. V. T. Chernobai, N. F. Komissarenko, and V. I. Litvinenko, Khim. Prirodn. Soedin., 51 (1968).

Khar'kov Scientific-Research Institute of Pharmaceutical Chemicals. Translated from Khimiya Prirodnykh Soedinenii, No. 3, p. 439, May-June, 1973. Original article submitted January 30, 1973.

() 1975 Plenum Publishing Corporation, 227 West 17th Street, New York, N.Y. 10011. No part of this publication may be reproduced, stored in a retrieval system, or transmitted, in any form or by any means, electronic, mechanical, photocopying, microfilming, recording or otherwise, without written permission of the publisher. A copy of this article is available from the publisher for $\$ 15.00$. 